\title{
Deciding to Urban-Migrate and Agricultural Development: Evidence from the Millennium Challenge Account (MCC)-Millennium Development Authority (MiDA) Intervention Zones, Ghana
}

\author{
Eric Ekobor-Ackah Mochiah', Robert Darko Osei'2, Isaac Osei Akoto ${ }^{2}$ \\ ${ }^{1}$ Faculty of IT Business, Ghana Technology University College, Accra, Ghana \\ ${ }^{2}$ Economics Division, Institute of Statistical, Social and Economic Research, Accra, Ghana \\ Email: ghostphase1@yahoo.com, rdosei@yahoo.co.uk, iokwame@yahoo.co.uk
}

Received 15 October 2014; revised 19 November 2014; accepted 3 December 2014

Copyright (C) 2014 by authors and Scientific Research Publishing Inc.

This work is licensed under the Creative Commons Attribution International License (CC BY).

http://creativecommons.org/licenses/by/4.0/

(c) (i) Open Access

\section{Abstract}

The decision to migrate involves both "push" and "pull" factors. Push factors force migrants out of rural areas while pull factors attract rural folks to the urban areas. The information set which displays the realities on the ground, if positive will motivate a potential migrant to move to an urban area and vice versa. Movement of labour for agriculture in the rural areas decreases resources needed to help promote the needed growth in the sector. With a sample size of 46,110 household members from two batches (about $\mathbf{3 0 0 0}$ farmers/households for each batch) of selected farmers who enjoyed agricultural interventions (technology), a probit model is estimated to find the factors that influence the decision to urban-migrate. In particular we discuss the question of whether the MiDA intervention through the training of farmers on various techniques/technologies to be more productive, has had an impact on farmers' as well as their household members' decision to urban-migrate. Generally, household, Farmer Based Organization and individual characteristics were considered in the model. We find that, farmers and their household members in the Southern Horticultural belt were less likely to migrate while those in the Northern Agricultural Zone were more likely to migrate to the urban area. Education, households with returned migrants, and remittances were positive in influencing the decision to urban-migrate. On the other hand, being self-employed and being married reduces the probability that an individual will migrate. General$l y$, the differential economic opportunities through the relative increased knowledge in the urban areas remain a pull factor of labour resources of the undeveloped rural agricultural sector. Bridg- 
ing the gap between the expected income differential of rural and urban areas resulting from differences in knowledge and opportunities will be the key to reducing this phenomenon as suggested by [4] and many other studies.

\title{
Keywords
}

\author{
Migration, Intervention, Decision, Ghana, Agriculture
}

\section{Introduction}

The most popular perception about why people migrate is often explained by the simple idea of obtaining a better standard of living but in reality it is a bit more complex. People may migrate not only because they are looking for better living standards but also perhaps for cultural reasons. According to [1], and [2], rural-urban migration is a response to the high demand of labour by an industrial sector, which assures workers greater levels of productivity, and investor's positive profits superior to the opportunities found in the traditional agricultural sector. According to these models rural regions are over-populated relative to their ability to feed themselves; labour productivity is low and approaching zero, which results in a subsistence level of production and provides incentives for migration to the cities. Expected, rather than current income differential are used to explain why individuals decide to move from the rural to urban areas ([3] and [4]) in less developed countries and until the expected urban income equals the rural income, people will continue to migrate. Reference [5] also argued that rural-urban migration occurs as a result of the perceived difference in income and standard of living between both areas.

Reference [6]-[8] suggested inclusion in the Harris-Todaro model, of information on costs of living and potential migrants' education levels when computing the probability of securing an urban job. According to [9] it is capital mobility, workers moving to places where capital is more productive, that leads to labour migration.

The decision to migrate involves both "push" and "pull” factors. Push factors force migrants out of rural areas while pull factors attract rural folks to the urban areas. A number of empirical researches have built on this ground to examine individual's motivation to migrate to the urban areas and primarily economic considerations were the most important reason (e.g. [10]-[12]). "Push" factors used in some studies include unemployment, lack of rural credit, rural poverty, lack of land, and perception of high wages from urban employment while the "Pull" factors used include urban educational opportunities, marriage and joining the family already at the destination.

Aside these, there is also the information flow influence. Consider that you have a relative, or a friend of the family, in an urban location or at least the name and address of somebody who knows your family and who will treat you sympathetically and assist with housing and finding a job, and perhaps has explained the rules of the game in the urban center, the two choices become clear enough to the potential migrant-whether to migrate or not. Information flow that displays the realities on the ground to be favourable and conducive to the potential migrant will be motivating enough to pull the individual to the urban area and vice versa.

It is in this light that this paper seeks to look into the decision to migrate from the rural to urban centers using data from the $3 \mathrm{MiDA}$ interventions zones in Ghana. In other words, what do individuals consider when they want to urban-migrate. The key issue of this study then, is to assess the MCA-Ghana programme which sought to reduce poverty by improving the production and productivity of farmers. A key feature of the programme was to increase commercialization of agriculture by eliminating the medium and long-term agriculture development bottlenecks. Farmers under the MCA programme underwent business and technical training. The training aimed at equipping farmers with skills in aspects of business numeracy, business literacy, agriculture production best practices, credit management, contract management, business plan development, and group formation and development. This was to help transform the subsistence way in which farmers undertake agriculture production.

Specifically, the study will try to find out

- Whether MiDA training reduces the probability of farmers and their household members migrating to urban areas; and

- The general contributing factors that promote individuals to make the decision to urban-migrate. 
Section 2 looks at some factors that influence the decision to migrate followed by Section 3 with the methodology. The fourth section presents the results and it is made up of descriptive statistics and results from the regression. Section 5 looks at the summary and conclusions with the 6th section highlighting the bibliography. Section 7 contains the appendix (Tables 11-14).

\section{Factors That Influence the Decision to Migrate}

There are several factors that has been researched on and suggested to be factors responsible for migration. Among them is the popular one of economic. Since the early 1990s Malaysia has become the major destination for Indonesian women migrant domestic workers. This trend arguably relates to the relative success of Malaysia's economic development program which has resulted in more job opportunities and higher salaries than are available in Indonesia. In addition, the close proximity of Indonesia and Malaysia ensures that travel between the two is relatively cheap. On another level, the assumed cultural and religious similarities make women feel that migrating to Malaysia is a "safe" option [13].

When discussing the movement of people between two sites, economists and demographers have largely focused their attentions on economic determinants. Existing research indicates that economic necessity is one of the fundamental issues that affect women's decisions to migrate [14]. According to [15], perceived wage differentials between domestic service in sending countries and receiving countries, combined with the lack of job opportunities for uneducated and unskilled women, have propelled many Indonesian women to migrate to Malaysia. Migration involves costs, risks and uncertainty. However, when the choice facing women with children to take care of is poorly paid domestic work in the home country or better paying domestic work abroad, it is not surprising that many opt for the latter. For many single mothers, divorcees and widows, lack of education and skills prevents them from securing rewarding employment in their area of origin, migration sometimes is the only viable economic option left for the survival of the family and the future of their children [16].

The lack of viable and financially rewarding economic alternatives in the home country is one of the reasons many educated Filipino women opt to work as domestic workers in other countries where they can gain higher financial rewards [17]. According to [18], more than 50 percent of Filipino women have been employed prior to migration, with the biggest concentration being in clerical work followed by domestic service. Even though these migrants were in paid work prior to migrating, the lack of attractive employment opportunities in the country of origin combined with more favourable working conditions in the destination country act as major pull and push factors in their decision to look for work overseas.

Migration is seen as substitute for well-paying jobs and consumer credit. For many households in less developed countries migration is not only a strategy to increase income, it is used to overcome failures in capital, credit and futures markets. Households attempt to overcome market failures by making an investment in the migration of one of its members. When the migrant member starts remitting, the household recovers its investment and the new income can be used to finance different family projects [19]-[24].

Remittances from migration can also be a very strong reason to migrate. This strategy is aimed at further socioeconomic advancement; in this case remittances are used to enhance the long-term economic status of households through investments in capital assets that will generate income. The use of remittances for this purpose is closely related to local markets and economic opportunities in sending communities [25]. Previous ethnographic work in Guatemala emphasizes that Mayan migrants who return from the United States find pride in owning land for agriculture, thus use remittances to acquire land—for maize and bean production—as well as for building a house [26]. In addition, remittances also allowed indigenous migrants to participate on the otherwise restricted Ladino land and cattle businesses, which "permits them to slowly challenge ethnic roles that have developed over the last five centuries” [26].

Additionally, in rural Mexico migrant remittances have been found to have indirect short-term effects and long-term asset accumulation effects on the level and distribution of farm income, land and livestock holdings [27]. Remittances are normally used for consumption purposes, including subsistence needs, household furnishings, and durable goods. Within this framework, migration is used for family maintenance, and not necessarily for socioeconomic mobility. In these households, after basic needs are met, remittances are more likely to be used for housing. While money investment on housing increases the wealth of households, it does not improve the income capacity of households.

Not only are migration decision based on economic reasons. Studies of overseas domestic workers from the 
Philippines indicate that significant numbers of Filipino women migrate for reasons other than economic necessity [28]. Reference [29] used an in-depth interview and indicated that women's decisions to migrate are a complex amalgam of economic necessity and the problems caused by the gender ideologies which pervade Indonesian society. In other words, economic motivation is only one of many complex reasons behind decisions made by women to migrate as domestic workers to Malaysia.

Reference [29] explained that the family units of some respondents in his study in Indonesia featured multiple asymmetrical power relations between husband and wife, mother and daughter, and father and daughter. He further explained that women and children have limited power and as such decisions of the parents are considered final with no chance at all for the decided-for-individual to make a decision. Decisions of marriage and education are made by the parents as [30] implied in his statement, 'within such complex structures (family units)... young girls and young women are among the least powerful.' In such a case if a young woman is married to a man who lives outside the locality, then the woman in question might migrate to join the husband. Even in instances where the women make education and marriage decisions, there would still be a potential migration for the reasons of marriage or education.

Occasionally, however, non-economic motives related to gender injustice can be dominant in a woman's decision to migrate. These motives include domestic violence and marital problems [14] [31]. In [29] work in Indonesia, sexual harassment emerged as the main motive in the case of one female respondent where she confessed that, rather than economic motives, the major influence for migrating had been the sexual harassment she endured from her brother-in-law.

\section{Methodology}

\subsection{Sampling and Stages of Sample Selection}

It was based on a randomized phase-in approach. It took advantage of the fact that not all FBOs' that were to be part of the programme could be trained at the same time and so implicit in the programme design itself was some degree of phasing. The study therefore took advantage of this and randomized the FBOs that were to be in the different phases of the training programme.

A Multistage selection approach involving both stratification and clustering of the sample was used. The stratification was based on the three zones (Southern Horticultural Belt, Afram Basin and the Northern Agricultural Zone). The sample is clustered at the FBO level. These zones in all had $23^{1}$ districts across the country.

The sample was selected in two stages. In the first stage, there was a selection of FBO's within each Zone. From 600 primed FBO's made available from Millennium Development Authority (MiDA), Institute of Statistical Social and Economic Research (ISSER) who were the evaluators of the agricultural part of the intervention, randomly selected the FBOs that were to be given early training against those that were to get late training. This was done in a participatory manner with the executives of these FBOs. In the second stage we randomly selected 5 farmers from each of the 600 FBOs.

This approach was done for both Batch I and Batch II farmers but at different times. The surveys were conducted over three (3) years during the life of the Compact, starting November 2008 through to January 2011. Based on sample adequacy considerations among others, approximately 1200 FBOs were designed to be interviewed as part of this evaluation. The Batch I FBO information was available in 2008. Consequently the two waves of the Batch I surveys were undertaken over the 2008 and 2009 periods. For the Batch II, the two waves of surveys were undertaken over the 2009 and 2010 period. For each Batch about 3000 farmers were selected to be interviewed and so in total about 6000 farmers and their households were interviewed.

The treatment took the form of offering training to members of the selected FBOs and a starter-pack (which consisted of seeds, fertilizer, a package for land preparation and other inputs as per the needs of that farmer).

\subsection{Econometric Model}

We adopt a probit model to examine the effect of the treatment on the individual's future decision to migrate to the urban area. We take advantage of the panel nature of the data and estimate a random effect model to identify the effect of treatment on the future decision of individuals to urban-migrate. The empirical model of interest is of the form:

\footnotetext{
${ }^{1}$ There are 30 districts in the MiDA intervention zones now instead of the original 23. This is due to administrative re-demarcation.
} 


$$
P\left(y_{i t}=1 \mid X_{i t}, f_{i}\right)=P\left(y_{i t}^{*}>0 \mid X_{i t}, \int_{i}\right)=\Phi\left(X_{i t} \beta+\int_{i}\right)
$$

where $y_{i t}$ is the dependent variable (outcome variable) which takes the value of one (1) when an individual decides to future migrate; otherwise, it is zero. $y_{i t}^{*}$ is the latent variable modeled under linear model assumptions, $\varepsilon_{i} \sim N(0,1)$ with $\Phi$ as the normal cumulative distribution function, $\beta$ is a vector of coefficients and $X_{i t}$ is also a vector which contains individual, household, FBO and other characteristics.

In getting the dependent variable, we looked at two main questions which were the factors that would be considered if an individual will want migrate in the future and where they were likely to migrate to. Based on the responses on the location, we selected our sample based on those that selected the capital towns of the 10 regions of Ghana. This was because all these towns are urban with population more than 5000 people (Ghana Census, 2010) and also majority of the sample chose those locations.

\subsection{Variables Generated and Used}

Table 1 presents a list of all the variables used in this study. The variables can be grouped into individual, household, FBO and other characteristics.

Table 1. Name of variables and their descriptions used in the study.

\begin{tabular}{|c|c|}
\hline Names of Variables & Description of variables \\
\hline \multicolumn{2}{|r|}{ Individual characteristics } \\
\hline Age & Age of individual \\
\hline Agesquared & The square of age \\
\hline Male & Takes the value of 1 if the individual is a male; otherwise zero \\
\hline Married & Takes the value of 1 if the individual is married; otherwise zero \\
\hline HHhead & Household head \\
\hline SelFBOmem & Selected FBO member \\
\hline Executive & FBO executive \\
\hline Noeduc & No education \\
\hline AboveSSS & Having education above senior high school level \\
\hline Writtencal & Whether an individual can do written calculations \\
\hline illinjury & If individual was ill or injured = 1 , otherwise zero \\
\hline Employee & Dummy where "being a paid employee" = 1 , and zero otherwise \\
\hline Selfemployed & Being self-employed = 1, zero otherwise \\
\hline \multicolumn{2}{|r|}{ Household characteristics } \\
\hline Rmigrant & Households with returned migrants is 1 ; otherwise zero \\
\hline TTRmigrant & Interaction of treat time and R migrant \\
\hline HHowns_dwelling & Household owns dwelling place = 1 ; otherwise zero \\
\hline electricity & Household's main source of lighting is electricity \\
\hline Wood_charc_waste & Household's main fuel for cooking is charcoal, wood or animal waste \\
\hline No_toilet & Households has no access to toilet facility \\
\hline Thatch_leaves_rafia & Household has either thatch or leaves or raffia as their roof \\
\hline Poor_housing & An interaction of Thatch_leaves_rafia and No_toilet \\
\hline roofIronsheet & Household has corrugated iron sheets as their roof \\
\hline
\end{tabular}




\begin{tabular}{|c|c|}
\hline Continued & \\
\hline hhsize & Household size \\
\hline Size_ha & Household total agriculture land size in hectares \\
\hline lTransfers & Log of amount of transfers into household \\
\hline Land_dispute & If household is involved in any land dispute \\
\hline Imp_drinking & Household has access to improved drinking water \\
\hline lloanamt & Total household loan amount \\
\hline lincome & Household crop income \\
\hline lincomesquare & Household crop income squared \\
\hline Land_dispute & Household was involved in land dispute \\
\hline Inherit & Household has inherited land \\
\hline right_land & Household has rights over land \\
\hline \multicolumn{2}{|c|}{ FBO characteristics } \\
\hline midazNAZ & Northern agricultural zone \\
\hline midazSHB & Southern horticultural belt \\
\hline \multicolumn{2}{|r|}{ Other characteristics } \\
\hline Batchdum & If individual is in Batch 2 of farmers = 1 ; otherwise zero \\
\hline Treatdum & Treatment $=1$ if selected FBO member got training, zero otherwise \\
\hline Time 2 & Time variable, where Time 2 = 1 if Period 2 , and zero otherwise \\
\hline Treattime & An interaction variable between the second period and treatment \\
\hline Urbmigrate & Ex-ante decision to urban-migrate $=1$; otherwise zero \\
\hline
\end{tabular}

The distribution of farmers across the MiDA zones is shown in Table 2. The distribution of the sampled farmers (ex-ante) across the three zones was respectively 27 percent, 39 percent and 34 percent for the Southern Horticultural Belt (SHB), Afram Basin (AFB) and Northern Agricultural Zone (NAZ) overall. The realized distribution across the two batches however differed slightly. For instance, in the batch one the distribution was about 26 percent, 41 percent and 33 percent respectively for Southern Horticultural Belt, Afram Basin and Northern Agricultural Zone. In the case of the batch two, the realized distribution of sample was respectively 27 percent, 38 percent, and 35 percent.

\section{Discussion of Results}

\subsection{Descriptive Statistics}

This section presents the demographic characteristics of the MiDA FBO members and their members. It also looks at information on household migration both ex-ante and ex-post. Demographic characteristics presented include sex, age, educational attainment, marital status and the relationship to the household head. Household characteristics such as age-sex composition, household sizes and sex of household head are also presented. The migration status and the reason for future migration are also presented. The tables are generated based on FBO members who completed the two rounds of surveys.

\subsection{Demographic Characteristics of MiDA FBO Members}

Table 3 shows the percentage distribution of the demographic characteristics of the selected MiDA FBO members who took part in the two surveys, by batch and MiDA zone. About 60 percent of the farmers in Batch I and 57 percent of the farmers in Batch II were males. For each Batch, there was a higher proportion of females in 
Table 2. Distribution of farmers across the MiDA zones.

\begin{tabular}{|c|c|c|c|c|c|c|c|c|c|}
\hline \multirow[b]{2}{*}{ MiDA Zones } & \multicolumn{3}{|c|}{ Batch 1} & \multicolumn{3}{|c|}{ Batch 2} & \multicolumn{3}{|c|}{ Overall } \\
\hline & 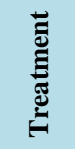 & ن & एٓ & 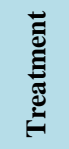 & 힣ㅁ & సٓ & 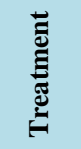 & 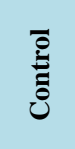 & 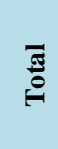 \\
\hline SHB & 25.9 & 26.1 & 26.0 & 27.8 & 26.4 & 27.1 & 26.8 & 26.3 & 26.6 \\
\hline AFB & 41.6 & 40.8 & 41.2 & 37.3 & 38.1 & 37.7 & 39.4 & 39.4 & 39.4 \\
\hline NAZ & 32.6 & 33.1 & 32.8 & 35.0 & 35.6 & 35.3 & 33.8 & 34.4 & 34.1 \\
\hline Total & 100 & 100 & 100 & 100 & 100 & 100 & 100 & 100 & 100 \\
\hline Chi-2 Test & \multicolumn{3}{|c|}{$\mathrm{P}$-value $=0.850$} & \multicolumn{3}{|c|}{$\mathrm{P}$-value $=0.490$} & \multicolumn{3}{|c|}{ P-value $=0.710$} \\
\hline
\end{tabular}

Table 3. Distribution of the background characteristics of MiDA FBO farmers by batch and MiDA Zone.

\begin{tabular}{|c|c|c|c|c|c|c|c|c|}
\hline \multirow{2}{*}{ Background characteristics } & \multicolumn{4}{|c|}{ Batch I } & \multicolumn{4}{|c|}{ Batch II } \\
\hline & SHB & AFB & NAZ & Total & SHB & AFB & NAZ & Total \\
\hline \multicolumn{9}{|l|}{ Sex } \\
\hline Male & 65.9 & 62.9 & 51.0 & 59.8 & 64.3 & 58.1 & 49.3 & 56.7 \\
\hline Female & 34.1 & 37.1 & 49.0 & 40.2 & 35.7 & 41.9 & 50.7 & 43.3 \\
\hline \multicolumn{9}{|l|}{ Age group (years) } \\
\hline Less than 20 & 0.2 & 0.2 & 1.0 & 0.5 & 0.0 & 0.1 & 0.2 & 0.1 \\
\hline $20-29$ & 4.6 & 5.9 & 11.7 & 7.4 & 5.7 & 9.2 & 13.6 & 9.8 \\
\hline $30-39$ & 21.9 & 26.2 & 28.5 & 25.8 & 24 & 28.5 & 30 & 27.8 \\
\hline $40-49$ & 33.4 & 31.0 & 26.8 & 30.3 & 34.5 & 26.6 & 26.3 & 28.6 \\
\hline $50-59$ & 23.7 & 23.9 & 18.8 & 22.2 & 23.2 & 22.2 & 16.3 & 20.4 \\
\hline 60 and over & 16.2 & 12.8 & 13.1 & 13.8 & 12.6 & 13.4 & 13.7 & 13.3 \\
\hline Mean age & 47.5 & 45.6 & 43.4 & 45.4 & 45.8 & 45.1 & 42.9 & 44.5 \\
\hline \multicolumn{9}{|l|}{ Relationship to $\mathrm{HH}$} \\
\hline Head of household & 82.7 & 75.9 & 56.4 & 71.4 & 80.7 & 72.0 & 51.9 & 67.3 \\
\hline Spouse of head & 15.8 & 23.7 & 39.6 & 26.8 & 18.7 & 27.3 & 42.7 & 30.4 \\
\hline Other & 1.4 & 0.4 & 4.0 & 1.8 & 0.6 & 0.7 & 5.4 & 2.4 \\
\hline \multicolumn{9}{|l|}{ Highest education } \\
\hline None & 16.7 & 27.8 & 81.8 & 42.4 & 18.2 & 23.6 & 82.8 & 42.9 \\
\hline Primary & 17.8 & 18.3 & 9.6 & 15.3 & 21.6 & 17.9 & 7.2 & 15.2 \\
\hline Middle/JHS & 44.3 & 43.6 & 3.6 & 30.8 & 45.3 & 46.0 & 5.0 & 31.4 \\
\hline Secondary+ & 21.2 & 10.3 & 5.0 & 11.4 & 15.0 & 12.5 & 4.9 & 10.5 \\
\hline
\end{tabular}

the NAZ than in the two other zones, especially in the SHB where the ratio of male to female farmers was about 2:1 compared to a corresponding ratio of almost 1:1 in the NAZ.

In terms of age, the age group 40 - 49 years emerges as modal age group of the farmers in both Batches, accounting for 30 and 29 percent respectively of Batch I and Batch II. Less than 1 in 6 of the farmers (about 13\%) 
were aged 60 years or over and the overall mean age of the farmers was about 45 years for both batches. The age pattern and resultant mean ages is similar across the three MiDA zones although the farmers in the NAZ are slightly younger on average.

About 7 in 10 of the farmers were the heads of their household and the rest were mainly the spouses of the heads of household. We note some differences across the MiDA zones. In the NAZ, the percentage of the farmers who were the heads of their household was lower compared to the other two Zones. In Batch I, about 83 percent of the farmers in the SHB indicated they were the heads of their household as compared to about 56 percent of the farmers in the NAZ. Also in Batch II, 81 percent of the farmers in the SHB indicated they were the heads of their household as compared to 52 percent of the farmers in the NAZ. This observation could be explained by the fact that the proportion of female farmers was higher in the NAZ and females are usually not heads of their household, especially in the NAZ.

Concerning marital status, about 83 percent of farmers in the Batch I were married with a further 4 percent in a consensual union. About 1 in 10 of them were divorced, separated or widowed and only 2 percent were never married. A higher proportion of the farmers in the Northern Agricultural Zone were married as compared to the other two zones (90\% for NAZ, 81\% for Southern Horticultural Belt and 79\% for Afram Basin).

The educational levels of the farmers were generally found to be low. For both batches, about 4 in 10 of the farmers have never been to school and only 1 in 10 has secondary or higher education. The lack of education was more pervasive among farmers from the northern zone with about 8 out of 10 of them not having any formal education. Despite these educational limitations, literacy and numeracy levels were quite encouraging. As shown in Table 4, about 50 percent of the farmers in each Batch were able to read simple sentences proficiently and about 70 percent were able to do a written calculation proficiently.

\subsection{Characteristics of Household Members of MIDA FBO Farmers}

The demographic characteristics of the household members of the selected FBO members are shown in Table 5. The distribution of the household members by sex shows near gender parity with either sex constituting approximately 50 percent of the number of household members. However, the same representation is not reflected on the sex of the head of household. The males dominating with about 87 percent and about 88 percent for the Batch I and Batch II respectively. Male dominance as household heads is more pronounced in the NAZ with more than 9 in 10 of all household heads being males.

Distribution of the household members by age shows a heavy representation at the base with more than 20 percent of the household members being age less than 10 years. The age group 10 - 19 accounts for the largest percentage of the household members across all the MIDA zones, accounting for about 26 percent of Batch I farmer households and about 25 percent of Batch II farmer households. Combining these two age groups shows that more than 50 percent of the household members are less than 20 years of age. On the upper end of the dis-

Table 4. Literacy and numeracy among FBO members.

\begin{tabular}{|c|c|c|c|c|c|c|c|c|}
\hline & \multicolumn{4}{|c|}{ Batch 1} & \multicolumn{4}{|c|}{ Batch 2} \\
\hline & SHB & AFB & NAZ & Total & SHB & AFB & NAZ & Total \\
\hline \multicolumn{9}{|l|}{ Literacy } \\
\hline Able to read proficiently & 55.4 & 50.9 & 38.0 & 51.3 & 49.5 & 44.7 & 51.5 & 47.3 \\
\hline Able to read but not proficiently & 20.2 & 16.7 & 12.7 & 17.6 & 22.7 & 21.3 & 9.9 & 20.6 \\
\hline Not able to read at all & 24.4 & 32.4 & 49.3 & 31.1 & 27.8 & 34.0 & 38.6 & 32.1 \\
\hline \multicolumn{9}{|l|}{ Numeracy } \\
\hline $\begin{array}{l}\text { Able to do written calculation } \\
\text { proficiently }\end{array}$ & 79.7 & 75.7 & 60.0 & 75.6 & 75.6 & 71.5 & 62.6 & 72.2 \\
\hline $\begin{array}{l}\text { Able to do written calculation } \\
\text { but not proficiently }\end{array}$ & 12.4 & 10.3 & 10.7 & 11.1 & 16.3 & 16.9 & 11.1 & 16.1 \\
\hline Not able to do written calculation & 7.9 & 14.0 & 29.3 & 13.3 & 8.1 & 11.5 & 26.3 & 11.8 \\
\hline Total & 100.0 & 100.0 & 100.0 & 100.0 & 100.0 & 100.0 & 100.0 & 100.0 \\
\hline
\end{tabular}


Table 5. Household characteristics of FBO farmers.

\begin{tabular}{|c|c|c|c|c|c|c|c|c|}
\hline \multirow{2}{*}{ Variables } & \multicolumn{4}{|c|}{ Batch 1} & \multicolumn{4}{|c|}{ Batch 2} \\
\hline & SHB & AFB & NAZ & Total & SHB & AFB & NAZ & SHB \\
\hline \multicolumn{9}{|c|}{ Sex of members } \\
\hline Male & 48.9 & 50.7 & 49.9 & 49.9 & 49.1 & 50.8 & 50.1 & 50.1 \\
\hline Female & 51.1 & 49.3 & 50.1 & 50.1 & 50.9 & 49.2 & 49.9 & 49.9 \\
\hline \multicolumn{9}{|c|}{ Sex of household head } \\
\hline Male & 81.4 & 86.5 & 91.0 & 86.6 & 83.4 & 85.3 & 93.4 & 87.6 \\
\hline Female & 18.6 & 13.5 & 9.0 & 13.4 & 16.6 & 14.7 & 6.6 & 12.4 \\
\hline \multicolumn{9}{|c|}{ Distribution of age of household members } \\
\hline $0-9$ & 22.2 & 26.4 & 31.4 & 27.4 & 24.8 & 28.2 & 33.1 & 29.6 \\
\hline $10-19$ & 28.4 & 28.5 & 23.9 & 26.6 & 28.3 & 26.1 & 23.3 & 25.4 \\
\hline $20-29$ & 14.7 & 11.2 & 15.2 & 13.7 & 11.9 & 10.8 & 13.5 & 12.3 \\
\hline $30-39$ & 10.3 & 10.8 & 10.1 & 10.4 & 11.0 & 11.4 & 10.5 & 10.9 \\
\hline $40-49$ & 11.0 & 11.0 & 8.2 & 9.9 & 11.9 & 10.7 & 8.8 & 10.2 \\
\hline $50-59$ & 7.4 & 7.4 & 5.2 & 6.5 & 7.3 & 7.2 & 5.3 & 6.4 \\
\hline $60-69$ & 3.2 & 2.8 & 3.5 & 3.2 & 3.0 & 3.6 & 3.3 & 3.3 \\
\hline $70-79$ & 1.8 & 1.3 & 1.9 & 1.7 & 1.2 & 1.3 & 1.6 & 1.4 \\
\hline $80+$ & 1.0 & 0.4 & 0.6 & 0.7 & 0.7 & 0.7 & 0.6 & 0.7 \\
\hline \multicolumn{9}{|c|}{ Household size } \\
\hline 1 & 17.7 & 19.2 & 13.2 & 16.4 & 19.6 & 20.4 & 13.8 & 17.3 \\
\hline $2-3$ & 33.5 & 34.7 & 26.0 & 30.9 & 35.8 & 36.2 & 26.8 & 31.9 \\
\hline $4-5$ & 26.5 & 26.4 & 23.1 & 25.1 & 27.1 & 26.0 & 23.6 & 25.2 \\
\hline $6-7$ & 13.9 & 13.4 & 17.0 & 15.0 & 12.7 & 12.0 & 16.7 & 14.2 \\
\hline $8-9$ & 5.0 & 4.5 & 10.2 & 6.9 & 3.9 & 3.8 & 9.6 & 6.4 \\
\hline $10+$ & 3.4 & 1.7 & 10.5 & 5.7 & .8 & 1.5 & 9.5 & 4.9 \\
\hline Mean household size & 3.90 & 3.66 & 5.05 & 4.28 & 3.51 & 3.52 & 4.91 & 4.13 \\
\hline
\end{tabular}

tribution, 0.7 percent are 80 years or older and less than 6 percent of them are 60 years of age or older. The median age is 18 years for Batch I and 17 years for Batch 2 with no much difference across zones.

The distribution of the household size shows that more than 50 percent of the households consist of more than 3 members and about 10 percent of the households consist of 8 or more members. Farmers in the NAZ tended to have larger household sizes with mean household size of 5.05 members for the Batch I farmers compared to 3.90 and 3.66 for the corresponding farmers in the SHB and AFB zones respectively. Average household size for the entire Batch I farmers is 4.28 persons. This pattern of the household size across the MiDA zones and the implied overall average household size is similar to the Batch II intake of farmers.

Table 6 shows the migration status for the sample population of FBO household members aged 7 and above in all batches and rounds of the FBO survey. In the FBO households studied, over 60 percent of the sample were non-migrants, that is, they have never been involved in any form of migration. The proportion of returned migrants was the least of all the migration statuses for all batches and rounds of the survey.

About 49.8 percent and 59.9 percent respectively in Waves 1 and 2 of the sample in Batch 1 said they would possibly migrate to the urban area in the future. In Batch 2, the proportion of potential migrants to the urban area 
Table 6. Migration status by treatment and control groups as well as by batch and round (\%).

\begin{tabular}{|c|c|c|c|c|c|c|}
\hline \multirow{2}{*}{ Migration Status } & \multicolumn{3}{|c|}{ Batch 1, Wave 1} & \multicolumn{3}{|c|}{ Batch 1, Wave 2} \\
\hline & Treatment & Control & Total & Treatment & Control & Total \\
\hline In-Migrants & 27.7 & 27.7 & 27.7 & 30.5 & 31.0 & 30.7 \\
\hline Returned Migrants & 9.4 & 11.5 & 10.4 & 7.6 & 7.7 & 7.6 \\
\hline Non-Migrants & 62.9 & 60.8 & 61.9 & 61.9 & 61.4 & 61.6 \\
\hline Total & 100 & 100 & 100 & 100 & 100 & 100 \\
\hline \multirow[t]{3}{*}{ Chi2 Test } & \multicolumn{3}{|c|}{$\mathrm{P}$-value $=0.003$} & \multicolumn{3}{|c|}{ P-value $=0.875$} \\
\hline & \multicolumn{3}{|c|}{ Batch 2, Wave 1} & \multicolumn{3}{|c|}{ Batch 2, Wave 2} \\
\hline & Treatment & Control & Total & Treatment & Control & Total \\
\hline In-Migrants & 29.2 & 28.5 & 28.8 & 26.7 & 27.1 & 26.9 \\
\hline Returned Migrants & 8.0 & 7.4 & 7.7 & 7.5 & 9.7 & 8.6 \\
\hline Non-Migrants & 62.8 & 64.1 & 63.5 & 65.8 & 63.2 & 64.5 \\
\hline Total & 100 & 100 & 100 & 100 & 100 & 100 \\
\hline Chi2 Test & \multicolumn{3}{|c|}{$\mathrm{P}$-value $=0.325$} & \multicolumn{3}{|c|}{$\mathrm{P}$-value $=0.000$} \\
\hline
\end{tabular}

decreased from 54.3 percent in Wave 1 to 45.2 percent in Wave 2 (Table 7).

Table 8 gives the proportion of potential migrants by MiDA intervention zones and it is obvious that many potential migrants to the urban area were in the Northern Agricultural belt with the least proportions being in the Southern Horticultural Belt.

Table 9 gives the potential reason for future migration to the urban area. Among these reasons, education was the most important in all Batches and Waves of data collected averaging over 25 percent. Seeking employment and accompanying parents are the next most important reasons after education respectively. Other family reasons, marriage, relocating business, health and war are some other reasons that were given as a possible cause of future migration to the urban area. War was the second most important reason given after education in Batch 1 Wave 1.

Accra was the most chose location by potential migrants. This is not surprising as Accra being a regional capital for Grater Accra Region, couple as the Capital of Ghana. This is followed by Tamale which is the regional capital of the Northern Region. This again is understandable following the fact that many of the potential migrants are from the Northern Agricultural zone. Kumasi which is the capital town of the Ashanti Region and one of Ghana's few cities follows. In Batch 2 Wave 2, Tamale is the most chosen urban destination followed by Accra and finally Kumasi.

\section{Regression Results}

The probit regression results reported in Table 10 (Equations (1) and (2), Equations (3) and (4), and Equations (5) and (6)) represent selected all members, FBO members and non-FBO members in the household who hand the intention to migrate in the future (ex-ante migration). The impact variable (treat-time) in all columns of the table was not significant implying the training had no influence on individual's decision to future migrate to the urban area irrespective of whether or not the member is a selected FBO member. From the variable Batchdum, the chances of household members in the second batch of selected farmers to urban-migrate reduces by 5.2 percentage points (Equation (1)), 6.5 percentage points (Equation (3)) and 4.7 percentage points (Equation (5)) respectively for all members, selected FBO members and Non-FBO members.

The probability of urban-migrating increases by about 2 percentage points if individuals are in the Northern Agricultural Zone (midazNAZ) while it reduces by 8 percentage points if they are in the Southern Horticultural Belt (midazSHB). Individuals in households with no rights over land (noright_land) are more likely to urbanmigrate with a probability of 7.1 percentage points for all household members, 8.3 percentage points for se- 
Table 7. Potential future migrants by treatment and control groups and MiDA zones.

\begin{tabular}{|c|c|c|c|c|c|c|}
\hline \multirow{2}{*}{ Future urban migration } & \multicolumn{3}{|c|}{ Batch 1, Wave 1} & \multicolumn{3}{|c|}{ Batch 1, Wave 2} \\
\hline & Treatment & Control & Total & Treatment & Control & Total \\
\hline Yes & 50.7 & 48.8 & 49.8 & 59.7 & 60.2 & 59.9 \\
\hline No & 49.4 & 51.2 & 50.2 & 40.3 & 39.8 & 40.1 \\
\hline Total & 100 & 100 & 100 & 100 & 100 & 100 \\
\hline \multirow[t]{2}{*}{ Chi2 Test } & \multicolumn{3}{|c|}{0.063} & \multicolumn{3}{|c|}{0.609} \\
\hline & \multicolumn{3}{|c|}{ Batch 2, Wave 1} & \multicolumn{3}{|c|}{ Batch 2, Wave 2} \\
\hline Yes & 53.6 & 55.1 & 54.3 & 45.5 & 45.0 & 45.2 \\
\hline No & 46.4 & 45.0 & 45.7 & 54.5 & 55.0 & 54.8 \\
\hline Total & 100 & 100 & 100 & 100 & 100 & 100 \\
\hline Chi2 Test & \multicolumn{3}{|c|}{0.104} & \multicolumn{3}{|c|}{0.577} \\
\hline
\end{tabular}

Table 8. Potential future migrants by treatment and control groups and MiDA zones.

\begin{tabular}{|c|c|c|c|c|c|c|}
\hline \multirow{2}{*}{ MiDA Zone } & \multicolumn{3}{|c|}{ Batch 1, Wave 1} & \multicolumn{3}{|c|}{ Batch 1, Wave 2} \\
\hline & Treatment & Control & Total & Treatment & Control & Total \\
\hline SHB & 16.9 & 21.5 & 19.0 & 23.9 & 24.8 & 24.3 \\
\hline AFB & 42.4 & 38.3 & 40.5 & 39.0 & 36.8 & 38.0 \\
\hline NAZ & 40.7 & 40.2 & 40.5 & 37.1 & 38.4 & 37.7 \\
\hline Total & 100 & 100 & 100 & 100 & 100 & 100 \\
\hline \multirow[t]{2}{*}{ Chi2 Test } & \multicolumn{3}{|c|}{0.000} & \multicolumn{3}{|c|}{0.180} \\
\hline & \multicolumn{3}{|c|}{ Batch 2, Wave 1} & \multicolumn{3}{|c|}{ Batch 2, Wave 2} \\
\hline SHB & 27.1 & 24.1 & 25.6 & 23.7 & 20.2 & 21.9 \\
\hline AFB & 33.4 & 34.0 & 33.7 & 31.1 & 34.9 & 33.0 \\
\hline NAZ & 39.5 & 41.9 & 40.7 & 45.3 & 44.9 & 45.1 \\
\hline Total & 100 & 100 & 100 & 100 & 100 & 100 \\
\hline Chi2 Test & \multicolumn{3}{|c|}{0.015} & \multicolumn{3}{|c|}{0.001} \\
\hline
\end{tabular}

lected FBO members and 6.7 percentage points for non-FBO members. Again individuals in households who have inherited land (inherit) would want to urban-migrate in the future. The chances are higher for selected FBO members ( 5.9 percentage points) than for non-members (2.6 percentage points). The size of household cultivated land (size_ha) reduces the chances of household members migrating to the urban area implying larger sizes translate to lower tendencies to migrate.

Household remittances received also influences the decision to migrate positively (ITranfers) by 0.7 percentage points generally as suggested by Taylor, et al., 2006. Income from crop sales (lincome) and the amount of loan received (lloanamt) by households create a positive likelihood for future migration to the urban area by its members -0.2 and 0.8 percentage points respectively in Equation (2). These outcomes could be explained from Equations (4) and (6). Non-members are the ones that are likely to migrate due to crop sales and not selected FBO members (Equation (6)). On the other hand, selected FBO members are likely to migrate if they were able to acquire loans (Equation (4)). After a certain threshold of income from crop sales, non-selected household members will not want to migrate in the future and this is measured by the variable lincomesquare. The number of people in a household (hhsize) also positively influences the decision to migrate by 0.7 percentage points for 
Table 9. Reason given for future urban migration and possible urban location of potential migrant.

\begin{tabular}{|c|c|c|c|c|c|c|c|c|c|c|c|c|}
\hline \multirow{2}{*}{$\begin{array}{l}\text { Reason for future } \\
\text { migration }\end{array}$} & \multicolumn{3}{|c|}{ Batch 1 Round 1} & \multicolumn{3}{|c|}{ Batch1 Round 2} & \multicolumn{3}{|c|}{ Batch 2 Round 1} & \multicolumn{3}{|c|}{ Batch 2 Round 2} \\
\hline & Treatment & Control & Total & Treatment & Control & I Total & Treatment & Control & Total & Treatment & Control & Total \\
\hline Job transfer & 3.3 & 4.1 & 3.7 & 2.0 & 3.3 & 2.6 & 1.8 & 1.7 & 1.7 & 2.8 & 2.4 & 2.6 \\
\hline Seeking employment & 11.3 & 14.3 & 12.7 & 21.3 & 20.2 & 20.8 & 20.7 & 20.7 & 20.7 & 20.7 & 20.5 & 20.6 \\
\hline Relocate business & 7.0 & 6.1 & 6.6 & 3.8 & 3.1 & 3.4 & 4.0 & 3.6 & 3.8 & 2.8 & 3.0 & 2.9 \\
\hline Spouse's employment & 3.5 & 3.8 & 3.6 & 4.6 & 4.0 & 4.4 & 3.6 & 3.9 & 3.8 & 4.7 & 5.2 & 4.9 \\
\hline Accompanying parent & 11.0 & 11.9 & 11.4 & 17.0 & 16.8 & 16.9 & 18.3 & 16.5 & 17.4 & 16.7 & 17.2 & 16.9 \\
\hline Marriage & 3.8 & 4.4 & 4.1 & 4.0 & 4.4 & 4.2 & 4.1 & 3.9 & 4.0 & 3.3 & 3.6 & 3.5 \\
\hline Other family reasons & 7.4 & 7.0 & 7.2 & 8.0 & 9.2 & 8.6 & 9.7 & 9.5 & 9.6 & 10.6 & 10.2 & 10.4 \\
\hline Political/Religious & 0.2 & 0.3 & 0.3 & 0.4 & 0.8 & 0.6 & 0.5 & 1.2 & 0.9 & 0.5 & 0.6 & 0.6 \\
\hline Education & 31.4 & 28.1 & 29.9 & 29.3 & 27.6 & 28.5 & 29.0 & 32.3 & 30.7 & 26.1 & 26.0 & 26.0 \\
\hline War & 14.5 & 13.0 & 13.8 & 4.7 & 4.3 & 4.5 & 3.3 & 1.6 & 2.5 & 5.0 & 5.2 & 5.1 \\
\hline Fire & 1.3 & 1.7 & 1.5 & 0.2 & 0.1 & 0.2 & 0.3 & 0.2 & 0.2 & 0.3 & 0.2 & 0.3 \\
\hline Flood/Famine/Drought & 4.1 & 3.6 & 3.9 & 3.8 & 5.0 & 4.4 & 3.8 & 4.2 & 4.0 & 5.9 & 5.5 & 5.7 \\
\hline Other & 1.3 & 1.5 & 1.4 & 1.0 & 1.2 & 1.1 & 0.9 & 0.7 & 0.8 & 0.4 & 0.3 & 0.4 \\
\hline Old age & 0.0 & 0.0 & 0.0 & 0.0 & 0.0 & 0.0 & 0.0 & 0.0 & 0.0 & 0.1 & 0.1 & 0.1 \\
\hline Health & 0.0 & 0.0 & 0.0 & 0.0 & 0.0 & 0.0 & 0.0 & 0.0 & 0.0 & 0.1 & 0.1 & 0.1 \\
\hline Total & 100 & 100 & 100 & 100 & 100 & 100 & 100 & 100 & 100 & 100 & 100 & 100 \\
\hline \multirow{2}{*}{$\begin{array}{l}\text { Urban area/Regional } \\
\text { capitals of Ghana }\end{array}$} & \multicolumn{3}{|c|}{ Batch 1 Round 1} & \multicolumn{3}{|c|}{ Batch 1 Round 2} & \multicolumn{3}{|c|}{ Batch 2 Round 1} & \multicolumn{3}{|c|}{ Batch 2 Round 2} \\
\hline & Treatment & Control & Total & Treatment & Control & Total & Treatment & Control & Total & Treatment & Control & Total \\
\hline Kumasi & 15.4 & 14.1 & 14.8 & 13.8 & 13.8 & 13.8 & 14.3 & 15.3 & 14.8 & 21.2 & 22.2 & 21.7 \\
\hline Sunyani & 1.9 & 1.6 & 1.8 & 0.6 & 0.6 & 0.6 & 0.8 & 0.7 & 0.7 & 1.2 & 2.3 & 1.7 \\
\hline Cape Coast & 4.8 & 5.3 & 5.0 & 1.9 & 1.6 & 1.7 & 1.6 & 1.1 & 1.4 & 1.5 & 2.2 & 1.9 \\
\hline Koforidua & 5.1 & 6.9 & 5.9 & 3.4 & 4.1 & 3.7 & 2.1 & 3.9 & 3.0 & 7.1 & 7.0 & 7.0 \\
\hline Accra & 38.2 & 38.0 & 38.1 & 57.2 & 56.2 & 56.8 & 59.4 & 52.7 & 56.0 & 29.2 & 26.2 & 27.7 \\
\hline Tamale & 25.2 & 26.9 & 26.0 & 18.3 & 19.4 & 18.8 & 17.1 & 21.4 & 19.3 & 32.4 & 33.0 & 32.7 \\
\hline Bolgatanga & 2.4 & 2.9 & 2.6 & 1.3 & 1.2 & 1.3 & 0.9 & 1.2 & 1.0 & 1.4 & 1.2 & 1.3 \\
\hline Wa & 2.4 & 1.2 & 1.8 & 0.4 & 0.3 & 0.4 & 0.5 & 0.5 & 0.5 & 0.7 & 0.2 & 0.5 \\
\hline Sekondi Takoradi & 0.7 & 0.6 & 0.6 & 0.7 & 0.4 & 0.5 & 0.7 & 0.3 & 0.5 & 1.5 & 1.3 & 1.4 \\
\hline Ho & 4.0 & 2.6 & 3.4 & 2.5 & 2.3 & 2.4 & 2.7 & 3.0 & 2.8 & 3.9 & 4.5 & 4.2 \\
\hline Total & 100 & 100 & 100 & 100 & 100 & 100 & 100 & 100 & 100 & 100 & 100 & 100 \\
\hline
\end{tabular}

selected FBO members and 1.1 percentage points for non-selected members. Overall, it increases the chance to migrate by 1.0 percentage points. Households with returned migrants (Rmigrants) positively influence the decision to migrate by 2.8 percentage points generally and 3.5 percentage points for non-FBO members. Returned migrants could act as evidence of how "good" or "bad" it is to migrate and this information flow or evidence plays a significant role in deciding to migrate.

Being an FBO executive (executive) reduces the probability of migrating by 2.6 percentage points overall and 
Table 10. Regression results for the decision to urban migrate by all household members, Selected FBO members and NonFBO members.

\begin{tabular}{|c|c|c|c|c|c|c|}
\hline & \multicolumn{2}{|c|}{ All household members } & \multicolumn{2}{|c|}{ Selected FBO member } & \multicolumn{2}{|c|}{ Non-FBO member } \\
\hline & Equation (1) & Equation (2) & Equation (3) & Equation (4) & Equation (5) & Equation (6) \\
\hline Variables & Urbmigrate & Urbmigrate & Urbmigrate & Urbmigrate & Urbmigrate & Urbmigrate \\
\hline \multirow[t]{2}{*}{ Time2 } & -0.007 & $-0.023^{* * *}$ & -0.014 & $-0.041^{* * *}$ & -0.005 & $-0.018^{* *}$ \\
\hline & $(0.007)$ & $(0.007)$ & $(0.014)$ & $(0.014)$ & $(0.008)$ & $(0.008)$ \\
\hline \multirow[t]{2}{*}{ Treatdum } & -0.004 & -0.003 & -0.010 & -0.010 & -0.002 & -0.001 \\
\hline & $(0.007)$ & $(0.007)$ & $(0.014)$ & $(0.014)$ & $(0.007)$ & $(0.007)$ \\
\hline \multirow[t]{2}{*}{ Treattime } & 0.008 & 0.001 & 0.004 & -0.003 & 0.009 & 0.001 \\
\hline & $(0.009)$ & $(0.009)$ & $(0.020)$ & $(0.020)$ & $(0.011)$ & $(0.011)$ \\
\hline \multirow[t]{2}{*}{ Batchdum } & $-0.052^{* * *}$ & $-0.066^{* * *}$ & $-0.065^{* * *}$ & $-0.086^{* * *}$ & $-0.047^{* * *}$ & $-0.061^{* * *}$ \\
\hline & $(0.005)$ & $(0.005)$ & $(0.010)$ & $(0.011)$ & $(0.005)$ & $(0.006)$ \\
\hline \multirow[t]{2}{*}{ midazSHB } & & $-0.077^{* * *}$ & & $-0.076^{* * *}$ & & $-0.076^{* * *}$ \\
\hline & & $(0.006)$ & & $(0.013)$ & & $(0.007)$ \\
\hline \multirow[t]{2}{*}{ midazNAZ } & & $0.020^{* * *}$ & & 0.018 & & $0.020^{* *}$ \\
\hline & & $(0.008)$ & & $(0.017)$ & & (0.009) \\
\hline \multirow[t]{2}{*}{ Land_dispute } & & 0.011 & & 0.003 & & 0.011 \\
\hline & & $(0.011)$ & & $(0.023)$ & & $(0.013)$ \\
\hline \multirow[t]{2}{*}{ inherit } & & $0.033^{* * *}$ & & $0.059^{* * *}$ & & $0.026^{* * *}$ \\
\hline & & $(0.005)$ & & $(0.011)$ & & $(0.006)$ \\
\hline \multirow[t]{2}{*}{ noright_land } & & $0.071^{* * * *}$ & & $0.083^{* * *}$ & & $0.067^{* * * *}$ \\
\hline & & $(0.007)$ & & $(0.014)$ & & $(0.008)$ \\
\hline \multirow[t]{2}{*}{ ITransfers } & & $0.007^{* * * *}$ & & $0.007^{* * *}$ & & $0.007^{* * *}$ \\
\hline & & $(0.001)$ & & $(0.002)$ & & $(0.001)$ \\
\hline \multirow[t]{2}{*}{ size_ha } & & $-0.004^{* * *}$ & & $-0.003^{*}$ & & $-0.005^{* * *}$ \\
\hline & & $(0.001)$ & & $(0.002)$ & & $(0.001)$ \\
\hline \multirow[t]{2}{*}{ lloanamt } & & $0.002^{* *}$ & & $0.004^{*}$ & & 0.002 \\
\hline & & $(0.001)$ & & $(0.002)$ & & $(0.001)$ \\
\hline \multirow[t]{2}{*}{ lincome } & & $0.008^{* * *}$ & & -0.003 & & $0.012^{* * *}$ \\
\hline & & $(0.003)$ & & $(0.006)$ & & $(0.003)$ \\
\hline \multirow[t]{2}{*}{ lincomesquare } & & $-0.001^{* *}$ & & 0.001 & & $-0.001^{* * *}$ \\
\hline & & $(0.000)$ & & $(0.001)$ & & $(0.000)$ \\
\hline \multirow[t]{2}{*}{ hhsize } & & $0.010^{* * *}$ & & $0.007^{* * *}$ & & $0.011^{* * *}$ \\
\hline & & $(0.001)$ & & $(0.002)$ & & $(0.001)$ \\
\hline \multirow[t]{2}{*}{ Rmigrants } & & $0.028^{* * *}$ & & 0.016 & & $0.035^{* * *}$ \\
\hline & & $(0.010)$ & & $(0.018)$ & & $(0.012)$ \\
\hline
\end{tabular}




\section{Continued}

\begin{tabular}{|c|c|c|c|}
\hline \multirow[t]{2}{*}{ TTRmigrant } & 0.016 & 0.007 & 0.032 \\
\hline & $(0.021)$ & $(0.034)$ & $(0.026)$ \\
\hline \multirow[t]{2}{*}{ Executive } & $-0.026^{* * *}$ & -0.009 & $-0.040^{* *}$ \\
\hline & $(0.010)$ & $(0.012)$ & $(0.019)$ \\
\hline \multirow[t]{2}{*}{ male } & -0.000 & -0.005 & -0.000 \\
\hline & $(0.005)$ & $(0.018)$ & $(0.006)$ \\
\hline \multirow[t]{2}{*}{ HHhead } & 0.008 & 0.018 & 0.012 \\
\hline & $(0.008)$ & $(0.019)$ & $(0.012)$ \\
\hline \multirow[t]{2}{*}{ married } & $-0.058^{* * *}$ & $-0.048^{* * *}$ & $-0.051^{* * *}$ \\
\hline & $(0.008)$ & $(0.017)$ & $(0.010)$ \\
\hline \multirow[t]{2}{*}{ Age } & $0.002^{* * *}$ & 0.002 & $0.002^{*}$ \\
\hline & $(0.001)$ & $(0.003)$ & $(0.001)$ \\
\hline \multirow[t]{2}{*}{ agesquared } & -0.00004 & -0.00004 & $-0.00004^{* * *}$ \\
\hline & $(0.000)$ & $(0.000)$ & $(0.000)$ \\
\hline \multirow[t]{2}{*}{ Self_employed } & $-0.066^{* * *}$ & $-0.090^{* * *}$ & $-0.059^{* * *}$ \\
\hline & $(0.005)$ & $(0.011)$ & $(0.006)$ \\
\hline \multirow[t]{2}{*}{ employee } & $-0.041^{* * *}$ & -0.035 & $-0.044^{* * *}$ \\
\hline & $(0.010)$ & $(0.022)$ & $(0.012)$ \\
\hline \multirow[t]{2}{*}{ writtencal } & $0.075^{* * *}$ & $0.028^{* *}$ & $0.086^{* * *}$ \\
\hline & $(0.005)$ & $(0.012)$ & $(0.006)$ \\
\hline \multirow[t]{2}{*}{ noeduc } & $0.020^{* * *}$ & $0.024^{*}$ & $0.018^{* * *}$ \\
\hline & $(0.006)$ & $(0.012)$ & $(0.006)$ \\
\hline \multirow[t]{2}{*}{ AboveSSS } & $0.038^{* *}$ & $0.048^{*}$ & 0.028 \\
\hline & $(0.019)$ & $(0.028)$ & $(0.026)$ \\
\hline \multirow[t]{2}{*}{ illinjury } & $-0.032^{* * *}$ & $0.039^{* * *}$ & $-0.059^{* * *}$ \\
\hline & $(0.007)$ & $(0.013)$ & $(0.009)$ \\
\hline \multirow[t]{2}{*}{ HHowns_dwelling } & $-0.010^{*}$ & $-0.025^{* *}$ & -0.006 \\
\hline & $(0.005)$ & $(0.011)$ & $(0.006)$ \\
\hline \multirow[t]{2}{*}{ wood_charc_waste } & $0.020^{* *}$ & 0.009 & $0.023^{* *}$ \\
\hline & $(0.010)$ & $(0.021)$ & $(0.012)$ \\
\hline \multirow[t]{2}{*}{ electricity } & $0.032^{* * *}$ & $0.030^{* * *}$ & $0.032^{* * *}$ \\
\hline & $(0.005)$ & $(0.011)$ & $(0.006)$ \\
\hline \multirow[t]{2}{*}{ Poor_housing } & $0.027^{* *}$ & 0.004 & $0.035^{* * *}$ \\
\hline & $(0.011)$ & $(0.024)$ & $(0.012)$ \\
\hline \multirow[t]{2}{*}{ imp_drinking } & 0.006 & 0.003 & 0.007 \\
\hline & $(0.005)$ & $(0.011)$ & $(0.006)$ \\
\hline Thatch_leaves_rafia & $-0.031^{* * *}$ & $-0.045^{* *}$ & $-0.028^{* *}$ \\
\hline
\end{tabular}




\section{Continued}

\begin{tabular}{|c|c|c|c|c|c|c|}
\hline & & $(0.010)$ & & $(0.022)$ & & $(0.012)$ \\
\hline \multirow[t]{2}{*}{ No_toilet } & & -0.004 & & -0.003 & & -0.006 \\
\hline & & $(0.009)$ & & $(0.020)$ & & $(0.010)$ \\
\hline \multirow[t]{2}{*}{ roofIronsheet } & & 0.003 & & $-0.036^{* *}$ & & 0.014 \\
\hline & & $(0.008)$ & & $(0.018)$ & & (0.009) \\
\hline \multirow[t]{2}{*}{ Constant } & $0.553^{* * *}$ & $0.462^{* * *}$ & $0.513^{* * *}$ & $0.560^{* * *}$ & $0.564^{* * *}$ & $0.437^{* * *}$ \\
\hline & $(0.005)$ & $(0.018)$ & $(0.011)$ & $(0.062)$ & $(0.006)$ & $(0.021)$ \\
\hline Observations & 46,110 & 46,110 & 10,349 & 10,349 & 35,761 & 35,761 \\
\hline R-squared & 0.003 & 0.041 & 0.004 & 0.035 & 0.002 & 0.042 \\
\hline
\end{tabular}

Standard errors in parentheses. ${ }^{* * *} \mathrm{P}<0.01 ;{ }^{* *} \mathrm{P}<0.05 ;{ }^{*} \mathrm{P}<0.1$.

4.0 percentage points for non-FBO members and this could be because of the position being held. Household members with the responsibility of marriage or are married (married) are not likely to migrate. There is a 4.8 percentage points and 5.1 percentage points chance of the married not migrating among the selected FBO member and non-members respectively. This might be because of the high responsibilities associated with being married and not wanting to leave the spouse behind. Age positively increases the chances of migrating by 0.2 percentage points and like income from crop sales as described above, age also has a threshold and above this threshold reduces the likelihood of migrating (age square). Individuals who have jobs (the self-employed and the paid employees) to do are not likely to leave their jobs and migrate. Generally, the self-employed (self_employed) are 6.6 percentage points less likely while the paid employees (employees) are 4.1 percentage points less likely to migrate. Non-FBO members are also 5.9 percentage points and 4.4 percentage points less likely to migrate if they are self-employed or paid employee respectively. Selected FBO members are 9.0 percentage points less likely to urban-migrate.

In terms of some educational variables, having the ability to do written calculation (writtencal) improves the chances of migrating to the urban area -7.5 percentage points, 2.8 percentage points and 8.6 percentage points for all household members, selected FBO members and non-FBO members respectively. Individuals with education levels above senior high school (AboveSSS) are more likely to migrate probably for higher education in the urban area as suggested in Table 9. In the same light, individuals with no education (noeduc) would also want to migrate and the likelihoods are 2.4 percentage points and 1.8 percentage points for selected FBO members and non-members respectively. As suggested by [6]-[8], the probability of securing an urban job has to do with information cost and the level of education of potential migrant and so the likelihood of an individual with high level of education getting an urban job is high. This could also be the reason for the positive influence of high education on the decision to migrate. Selected FBO members who were either injured or ill two weeks before the survey (illinjury) were 3.9 percentage points more likely to migrate. However, non-FBO member in similar condition were 5.9 percentage points less likely to migrate.

Household housing characteristics also had its share of influences on its members' decision to migrate. Individuals in households that own their dwelling (HHowns_dwelling) were less likely to migrate by 1.0 percentage points generally and 2.5 percentage points if individual is a selected FBO member. Households that use as their main cooking fuel wood, charcoal or animal waste relative to others like LPG and electricity (wood_charc waste) had its non-FBO members and overall members being more likely to migrate (2.3 percentage points and 2.0 percentage points). If electricity is the main source of lighting for households, its members are more likely to migrate to the urban area (3.2 percentage points). This may be because they see the impact of having electricity in one's social life and the ability to enjoy more amenities that are limited or not available in the rural setting. The variable Poor_housing is an interactive variable of households that have no toilet facility and uses Thatch, leaves or Raffia as their roof. This is positive and so increases the likelihood of its members wanting to migrate 
by 2.7 percentage points and 3.5 percentage points for only non-FBO members. Selected FBO-members in households with their roofing being corrugated iron sheets (roofIronsheet) are less likely to migrate with a probability of 3.6 percentage points. Generally all individual with thatch, leaves or raffia are less likely to migrate (3.1 percentage points). Generally from the above variables, poor housing is synonymous with poor households and as such these households are more likely to want to seek better conditions elsewhere, hence might migrate to the urban area.

\section{Summary, Conclusions and Recommendations}

The study provides an assessment of the MiDA training on farmers and their household members' decision to urban-migrate. We look at the various factors that could act as "push" or "pull” factors as well as general factors that will influence the individual to make the decision to migrate to the urban area in the future. A probit regression is used to estimate the determinants of the decision to urban-migrate. Generally, household, FBO and individual characteristics were considered in the model.

We find that, farmers and their household members in the Southern Horticultural belt were less likely to migrate while those in the Northern Agricultural Zone were more likely to migrate to the urban area. The major destination chosen by these potential migrants were Accra, Tamale and Kumasi which are the capital towns of Greater Accra, Northern and Ashanti regions.

Remittances were seen as an important pull factor since it was positively influencing the decision to migrate. Again households with returned migrants were more likely to migrate and this clearly is from the point of view of information sharing. The evidence provided by these returned migrants encourages other household members to want to migrate. However, farmers that were executive members of FBOs as well as household members that were married were not likely to migrate. This is probably due to the responsibilities they hold. Household members that had their own jobs to do or considered self-employed were not willing to leave their jobs behind.

Education plays a major role in the decision to migrate to the urban area. From the descriptive statistics in Table 9, it was clear that majority of individuals will want to migrate due to education and this was confirmed in the probit model by the education variables. Individuals with education level above senior high school will want to urban-migrate. This could be explained by Harris-Todaro model of expectations of high earnings in the destination area as opposed to the current area of residence. Higher earnings are correlated with higher education and as such those individuals with higher education will want to move to areas that they expect to receive higher earnings. On the contrary, those with no education will also want to migrate and this could be explained by the expected job opportunities that are perceived to exist in the urban areas (Table 9).

Household housing characteristics of households with poor roofing and no toilet facilities increases the chance of one migrating to the urban-area. Electricity in households promotes migration maybe for want of more amenities that are non-existent in the rural areas even though there is electricity.

It is evident in the study that the MiDA training has no impact on the decision to migrate to the urban area but poor housing characteristic, remittances and education do positively influence individuals' decision to migrate.

By way of recommendations, more economic opportunities through increased productivity to bridge the gap between the expected income differential of rural and urban areas will be key as [4] suggested. Aside this, a lot more work should be targeted at ex-ante as oppose to ex-post situations as the adverse effect of migration could be mitigated through research findings before the actual migration process takes place.

\section{References}

[1] Lewis, W.A. (1954) Economic Development with Unlimited Supply of Labour. The Manchester School, 22, $139-191$. http://dx.doi.org/10.1111/j.1467-9957.1954.tb00021.x

[2] Fei, J.C.H. and Ranis, G. (1961) A Theory of Economic Development. The American Economic Review, 51, 533-565.

[3] Todaro, M. (1969) A Model of Labour Migration and Urban Unemployment in Less Developed Countries. The American Economic Review, 59, 138-148.

[4] Harris, J.R. and Todaro, M.P. (1970) Migration, Unemployment and Development: A Two-Sector Analysis. American Economic Review, 60, 126-142.

[5] Moyosola, O.A. (2007) Rural-Urban Migration and Productivity in Nigerian Agricultural Sector. MA Thesis, Simon Fraser University, Bumaby.

[6] Gugler, J. and Flanagan, W.G. (1978) Urbanization and Social Change in West Africa. Cambridge University Press, 
New York.

[7] Fields, G.S. (1979) Place-to-Place Migration: Some New Evidence. The Review of Econometrics \& Statistics, 61, 2132. http://dx.doi.org/10.2307/1924827

[8] Kelly, A.C. and Williamson, J.G. (1984) What Drives Third World City Growth? A Dynamic General Equilibrium Approach. The Princeton University Press, New York.

[9] Corden, W.M. and Findlay, R. (1975) Urban Unemployment Inter-Sectoral Capital Mobility and Development Policy. Economica, 42, 59-78. http://dx.doi.org/10.2307/2552986

[10] Brigg, P. (1973) Some Economic Interpretations of Case Studies of Urban Migration in Developing Countries. World Bank Staff Working Paper. World Bank, Washington DC. http://documents.worldbank.org/curated/en/1973/03/1555285/some-economic-interpretations-case-studies-urban-migra tion-developing-countries

[11] Connell, J., Dasgupta, B., Laishly, R. and Lipton, M. (1977) Migration from Rural Areas: Evidence from Village Studies. Oxford University Press, New Delhi.

[12] Baril, R., Joel, G. and Rulx-Leonel, J. (1986) Exodus as a Strategy of Survival: The Case of Rural Haiti. Environmental Caraibe, 2, 69-104.

[13] Dewi, A. (2006) Dream Seekers: Indonesian Women as Domestic Workers in Asia. Equinox Publishing, Jakarta.

[14] Parrenas, R.S. (2001) Servants of Globalization: Women, Migration, and Domestic Work, Stanford California. Stanford University Press, Stanford.

[15] Malsiri, D. (1989) Female Overseas Contract Workers: Sri Lanka. In: Trade in Domestic Helpers: Causes, Mechanisms, and Consequences, Asian and Pacific Development Centre, Kuala Lumpur, 207-234.

[16] Lim, L.L. (1990) The Status of Women and International Migration. In: International Migration Policies and the Status of Female Migrants, Proceedings of the Expert Group Meeting on International Migration Policies and the Status of Female Migrants, San Miniato, 28-31 March 1990, United Nations, New York, 29-55.

[17] Paz-Cruz, V., Paganoni, A., et al. (1989) Filipinas in Migration: Big Bills and Small Change. Scalabrini Migration Center, Manila.

[18] Asia Pacific Mission for Migrant Filipinos (2001) Case Study of the Development of Filipino Migrants’ Movement in Some Selected Countries in the Asia Pacific and Middle East Regions. Submitted to Asia Pacific Women Law and Development Task Force on Labor and Migration, 8.

[19] Stark, O. and Lucas, R.E.B. (1998) Migration, Remittances and the Family. Economic Development and Cultural Change, 36, 465-481. http://dx.doi.org/10.1086/451670

[20] Stark, O. and Taylor, J.E. (1991) Migration Incentives, Migration Types: The Role of Relative Deprivation. The Economic Journal, 101, 1163-1178. http://dx.doi.org/10.2307/2234433

[21] Massey, D.S., Jorge, D. and Nolan, J.M. (2002) Beyond Smoke and Mirrors: Mexican Immigration in an Era of Economic Integration. Russell Sage Foundation, New York.

[22] Mariano, S. and Massey, D.S. (2005) Household Composition, Family Migration, and Community Context: Migrant Remittances in Four Countries. Social Science Quarterly, 86, 509-528. http://dx.doi.org/10.1111/j.0038-4941.2005.00315.x

[23] Goldring, L. (2004) Family and Collective Remittances to Mexico: A Multi-Dimensional Typology. Development and Change, 35, 799-840. http://dx.doi.org/10.1111/j.0012-155X.2004.00380.x

[24] Kritz, M.M., Lim L.L. and Zlotnik, H. (1992) International Migration Systems: A Global Approach. Clarendon Press, Oxford University Press, Oxford.

[25] Lindstrom, D.P. (1996) Economic Opportunity in Mexico and Return Migration from the United States. Demography, 33, 357-374. http://dx.doi.org/10.2307/2061767

[26] Taylor, M.J., Michelle, J.M. and Debra, R.R. (2006) Land, Ethnic and Gender Change: Transnational Migration and Its Effects on Guatemalan Lives and Landscapes. Geoforum, 37, 41-61. http://dx.doi.org/10.1016/j.geoforum.2004.12.002

[27] Taylor, J.E. (1992) Remittances and Inequality Reconsidered: Direct, Indirect, and Intertemporal Effects. Journal of Policy Modeling, 14, 187-208. http://dx.doi.org/10.1016/0161-8938(92)90008-Z

[28] Caridad, T. (1989) Filipina Maids in Malaysia. In: Trade in Domestic Helpers: Causes, Mechanisms, and Consequences, Asian and Pacific Development Centre, Kuala Lumpur, 272-286.

[29] Gaffar, Z.H. (2008) Deciding to Migrate: Factors, Influences, and Processes in the Experiences of Indonesian Women who Migrate to Malaysia as Domestic Workers. Intersections: Gender and Sexuality in Asia and the Pacific, 17, 1-11.

[30] Arizpe, L. (1981) Relay Migration and the Survival of the Peasant Household. In: Balan, J., Ed., Why People Move: 
Comparative Perspectives on the Dynamics of Internal Migration, Unesco Press, Paris, 187-210.

[31] Frank, E. (1990) Migration of Sri Lankan Women to Western Asia. In: International Migration Policies and the Status of Female Migrants, Proceedings of the Expert Group Meeting on International Migration Policies and the Status of Female Migrants, San Miniato, 28-31 March 1990, United Nations, New York, 267-277. 
Appendix

Table 11. Migration status by age, treatment and control groups for Batch 1 (\%).

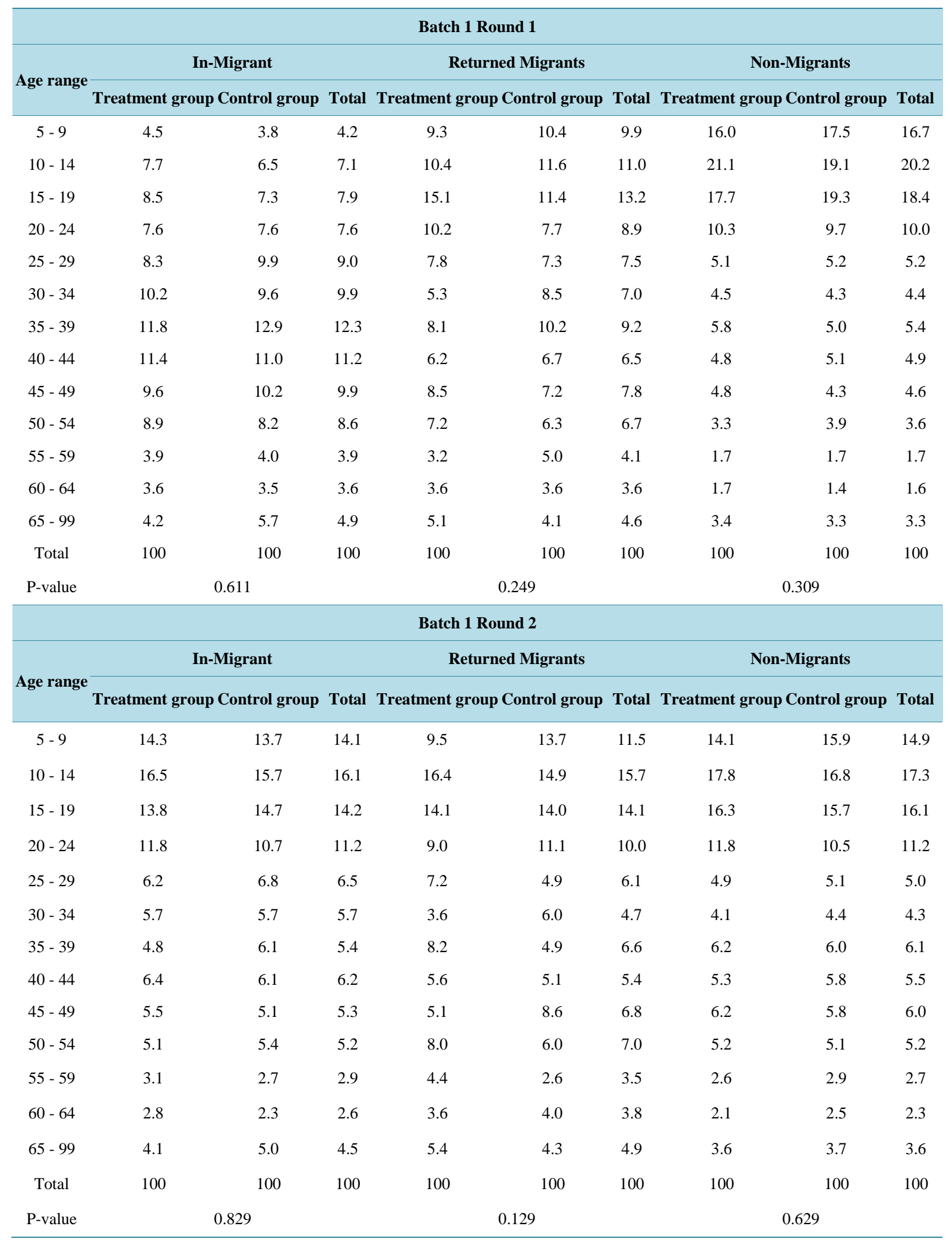


Table 12. Migration status by age, treatment and control groups for Batch 2 (\%).

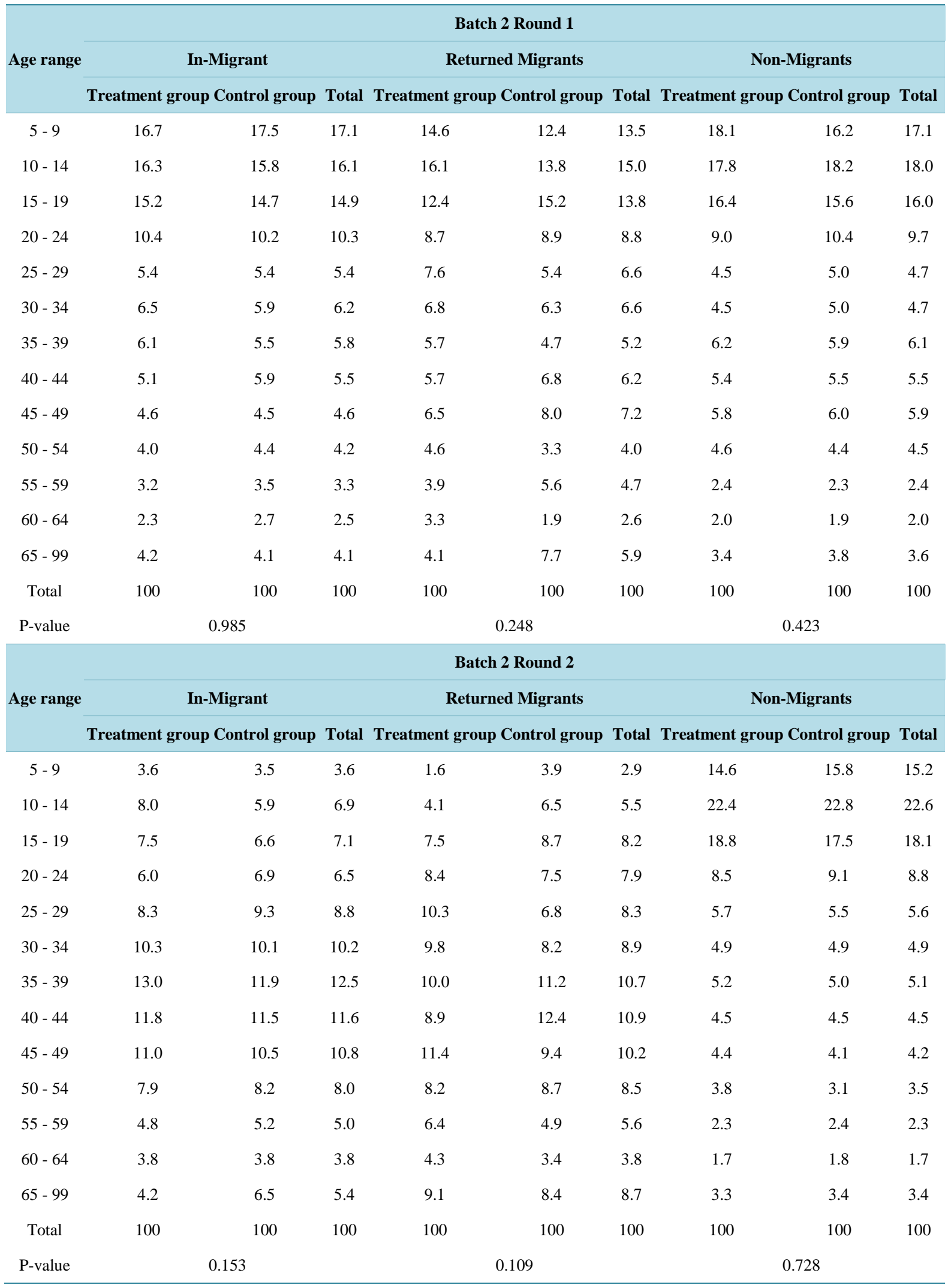


Table 13. Potential future migrants by treatment and control groups and sex.

\begin{tabular}{|c|c|c|c|c|c|c|}
\hline \multicolumn{4}{|c|}{ Male } & \multicolumn{3}{|c|}{ Female } \\
\hline \multicolumn{7}{|c|}{ Batch 1 Round 1} \\
\hline Future migration & Treatment & Control & Total & Treatment & Control & Total \\
\hline Yes & 51.67 & 49.79 & 50.81 & 49.6 & 47.88 & 48.78 \\
\hline \multicolumn{7}{|c|}{ Batch 1 Round 2} \\
\hline Yes & 58.77 & 62.06 & 60.28 & 60.64 & 58.34 & 59.54 \\
\hline \multicolumn{7}{|c|}{ Batch 2 Round 1} \\
\hline Yes & 53.84 & 55.76 & 54.81 & 53.34 & 54.32 & 53.82 \\
\hline \multicolumn{7}{|c|}{ Batch 2 Round 2} \\
\hline Yes & 46.71 & 46.47 & 46.59 & 44.28 & 43.48 & 43.88 \\
\hline
\end{tabular}

Table 14. Potential future migrants by treatment and control groups and education group.

\begin{tabular}{|c|c|c|c|c|c|c|}
\hline \multirow{3}{*}{ Education group } & \multicolumn{3}{|c|}{ Batch 1 Round 1} & \multirow{2}{*}{\multicolumn{3}{|c|}{ Control }} \\
\hline & \multicolumn{3}{|c|}{ Treatment } & & & \\
\hline & No & Yes & Total & No & Yes & Total \\
\hline No education & 64.38 & 63.77 & 64.04 & 66.37 & 65.17 & 65.73 \\
\hline SSS and below & 32.55 & 33.97 & 33.33 & 29.84 & 31.9 & 30.96 \\
\hline Above SSS & 3.07 & 2.26 & 2.63 & 3.78 & 2.93 & 3.32 \\
\hline Total & 100 & 100 & 100 & 100 & 100 & 100 \\
\hline \multicolumn{7}{|c|}{ Batch 2 Round 1} \\
\hline No education & 66.32 & 66.48 & 66.41 & 65.83 & 63.81 & 64.66 \\
\hline SSS and below & 32.21 & 31.39 & 31.75 & 32.01 & 33.84 & 33.07 \\
\hline Above SSS & 1.47 & 2.12 & 1.84 & 2.16 & 2.35 & 2.27 \\
\hline Total & 100 & 100 & 100 & 100 & 100 & 100 \\
\hline
\end{tabular}


Scientific Research Publishing (SCIRP) is one of the largest Open Access journal publishers. It is currently publishing more than 200 open access, online, peer-reviewed journals covering a wide range of academic disciplines. SCIRP serves the worldwide academic communities and contributes to the progress and application of science with its publication.

Other selected journals from SCIRP are listed as below. Submit your manuscript to us via either submit@scirp.org or Online Submission Portal.
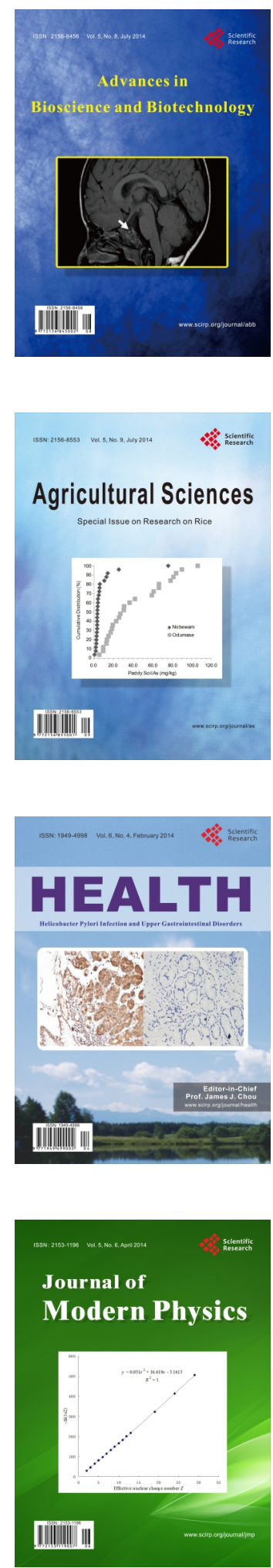
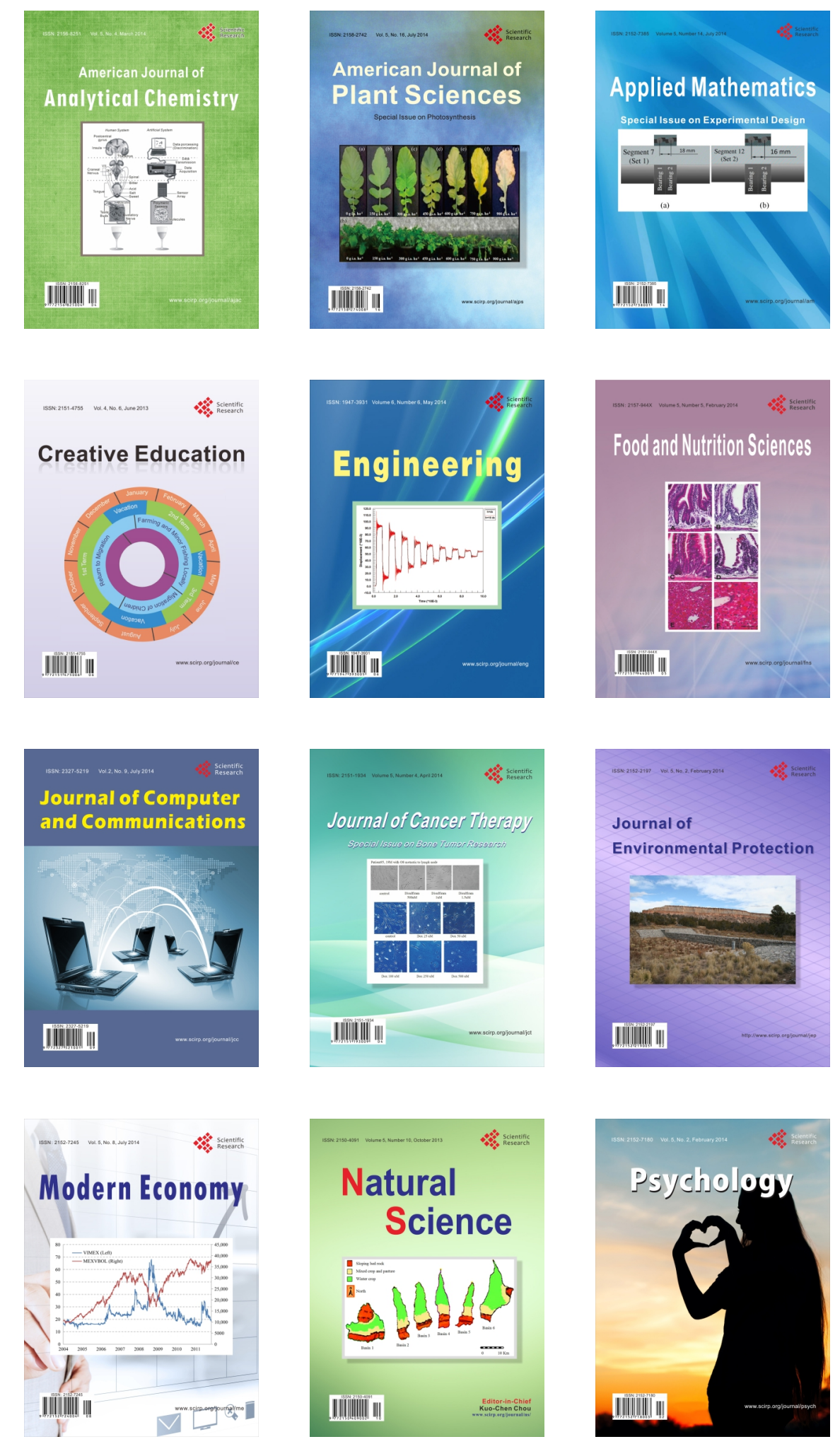